\title{
Mathematical Markup Language
}

National Cancer Institute

\section{Source}

National Cancer Institute. Mathematical Markup Language. NCI Thesaurus. Code C71609.

An application of XML for describing mathematical notations and capturing both its structure and content. It aims at integrating mathematical formulae into World Wide Web documents. 